\title{
Urgensi Ranah Afektif \\ Dalam Evaluasi Pendidikan Agama Islam Di Perguruan Tinggi Umum
}

\author{
Ahmad Darmadji \\ Program Studi Pendidikan Agama Islam, Fakultas IImu Agama Islam (FIAI) \\ Universitas Islam Indonesia
}

\begin{abstract}
Abstrak:
Terabaikannya ranah afektif pada evaluasi PAI di PTU disebabkan sejumlah faktor. Pertama, perbedaan persepsi tentang batasan materi yang tidak dapat dievaluasi seperti masalah keimanan. Kedua, perumusan tujuan PAl terlalu ideal dan kurang jelas sehingga sulit diukur. Ketiga, kurangnya kemampuan sebagian besar dosen PAI dalam mengembangkan instrumen PAI pada ranah afektif. Keempat, tingginya rasio dosen dengan jumlah mahasiswa. Untuk mengatasi. persoalan tersebut, diperlukan pendalaman terhadap pemahaman ranah afektif pada PAI. Disamping itu, diperlukan juga pengayaan teknik dan mekanisme pelaksanaan evaluasi PAI dengan memperhatikan mahasiswa sebagaipeserta didik dewasa.
\end{abstract}

\section{Pendahuluan}

ebagaimana dimaklumi bersama bahwa pendidikan agama Islam (PAl) -bahkan pendidikan apapunmerupakan proses yang melibatkan sejumlah unsur. Unsur-unsur tersebut antara lain: unsur insani dan unsur non insani. Unsur insani bertaut dengan subyek (peserta didik dan pendidik) serta orang lain di sekitarnya, sedangkan unsur non-insani berhubungan dengan tujuan, materi, media pendidikan, sarana prasarana pendukung dan lingkungan di mana proses pendidikan dilakukan. Di sisi lain, ketercapaian tujuan dan hasil pendidikan dipengaruhi banyak faktor, mulai faktor proses hingga faktor lain sebagaimana disebutkan di atas. Tercapai-tidaknya tujuan tersebut juga perlu diketahui banyak pihak, mulai pendidik dan peserta didik hingga masyarakat luas. Ketercapaian tujuan dan hasil pendidikan tersebut antara lain diketahui melalui proses penilian dan evaluasi.

Selain itu dimaklumi juga bahwa tujuan dan hasil pendidikan setidaknya diharapkan mencakup tiga ranah penting: kognitif, psikomotorik dan afektif sebagaimana lebih sering dikenal dengan istilah taksonomi Bloom (Bloom, 1956). Sependapat dengan Bloom, Anderson (1981) menyatakan bahwa ketiga ranah tersebut sesuai dengan karakteristik atau tipikal manusia dalam berpikir, berbuat dan berperasaan. Tipikal berpikir berkaitan dengan ranah kognitifyaitu yang berhubungan dengan cara berfikir yang khas, tipikal berbuat berkaitan dengan ranah psikomotor, yaitu yang berhubungan dengan cara bertindak yang khas dan tipikal perasaan berkaitan dengan ranah afektif. Ranah afektif yaitu cara yang khas dalam merasakan atau mengungkapkan emosi, dan mencakup watak perilaku seperti perasaan, minat, sikap, emosi, atau nilai. Ketiga ranah tersebut merupakan karakteristik manusia sebagai hasil belajar dan proses pendidikan pada umumnya Pada konteks ini, karakteristik tersebut dipahami sebagai kualitas yang menunjukkan cara-cara khusus manusia dalam berikir, bertindak dan merasakan dalam berbagai suasana (Zuhdi, 2008). 
Untuk mengetahui perkembangan tujuan pendidikan dan hasil belajar, diperlukan penilaian dan evaluasi secara menyeluruh, sistematik, sistemik dan terstandar. Sesuai Peraturan Menteri Pendidikan Nasional No. 20 Tahun 2007 tentang Standar Penilaian, standar penilaian pendidikan pada umumya adalah standar yang berkaitan dengan mekanisme, prosedur dan instrumen penilaian hasil belajar peserta didik. Sebelumnya, Peraturan Pemerintah (PP) nomor 19 tahun 2005 pasal 63 telah menegaskan bahwa penilaian pendidikan pada jenjang pendidikan tinggi khususnya, terdiri atas: (1) penilaian hasil belajar oleh pendidik, dan (2) penilaian hasil belajar oleh satuan pendidikan tinggi.

Terkait dengan penilaian dan evaluasi hasil belajar bidang PAl di perguruan tinggi umum (PTU), secara formal sistem evaluasi PAI merujuk pada sistem penilaian program mata kuliah dasar umum (MKDU) yang menerapkan prinsip-prinsip perolehan secara berimbang antara tiga komponen. Ketiga komponen dimaksud adalah: (1) perolehan pengetahuan dan pemahaman; (2) pembentukan keterampilan intelektual dan hubungan antar pribadi, dan (3) pembentukan dan pengamalan nilai (Syahidin, 2010). Ketiga komponen tersebut mencerminkan suatu konsepsi pembinaan keperibadian secara menyeluruh, berimbang dan berkesinambungan. Prinsip di atas perlu dijabarkan secara operasional sehingga hasil pendidikan PAl dapat dievaluasi dengan baik.

Selama ini evaluasi PAI di PTU pada umumnya baru sampai pada penǵukuran aspek intelektual-kognitif secara formal seperti ujian tengah semester (UTS) dan ujian akhir semester (UAS). Di sisi lain, aspek perubahan tingkah laku (psikomotorik) dan afektif belum dilakukan secara memadai. Disadari juga bahwa ranah afektif merupakan ranah atau domain yang sering terabaikan, dan bahkan hal ini terjadi hampir pada semua jenjang atau satuan pendidikan. Dengan gambaran singkat terșebut, tulisan ini mencoba mengupas mengapa hingga saat ini keterabaian ranah afektif itu masih terjadi. Selanjutnya, tulisan ini mengajukan pula sejumlah upaya yang dapat dilakukan untuk meminimalisir terabaikannya ranah afektif dalam PAI. Diharapkan, senarai gagasan pada tulisan ini dapat berkontribusi dalam mengurangi terabaikannya ranah afektif dalam proses pendidikan dan penilaian PAI pada perguruan tinggi umum (PTU). Guna mendukung pembahasan, tulisan ini memuat tinjauan tentang mata kuliah PAI di PTU, tinjauan teori ranah afektif, dan penilaian/ evaluasi ranah afektif.

\section{PAI șebagai Mata Kuliah Dasar Umum (MKDU)}

Hasil sidang pleno Badan Standar Nasional Pendidikan (BNSP) pada 22 Desember 2006 tentang Panduan Penilaian Kelompok Agama dan Akhlak Mulia menetapkan bahwa Pendidikan Agama, termasuk PAI pada semua jenjang atau satuan pendidikan, dimaksudkan untuk peningkatan potensi atau kemampuan spiritual dan membentuk peserta didik agar menjadi manusia yang beriman dan bertakwa kepada Tuhan Yang Maha Esa dan berakhlak mulia. Akhlak mulia mencakup etika (baik-buruk, hak-kewajiban), budi pekerti (tingkah laku), dan moral (baik-buruk menurut umum) sebagai perwujudan dari pendidikan.

Hal demikian tidak terkecuali PAl pada perguruan tinggi umum (PTU) yang ditetapkan sebagai salah satu mata kuliah dasar umum (MKDU) dengan bobot 2 SKS. Sekalipun alokasi waktunya sangat terbatas, tidak jarang PTU menggantungkan harapan yang tinggi, sehingga setelah menempuh mata kuliah PAI diharapkan mahasiswanya memiliki kompetensi yang memadai dalam bidang agama Isiam. Sebuah PTUN dalam silabi PAInya antara lain menetapkan bahwa setelah mengikuti mata kuliah PAl diharapkan mahasiswa memiliki kompetenși sebagai berikut: (1) Mahasiswa menguasai ajaran Islam dan menjadikannya sebagai sumber nilai, pedoman dan landasan berfikir dan berperilaku dalam menerapkan ilmu dan profesi yang dijalaninya; (2) Menjadikan "capital intellectual" yang beriman dan bertakwa kepada Allah Swt, berakhlak mulia dan berkepribadian Islami (Elan Sumarna, 2009).

Bila ruang lingkup materi PAl umumnya mencakup Al-Qur'an, Hadits, Aqidah, Akhlak, Fikih, Tarikh dan Kebudayaan Islam, namun pada sejumlah PTU cakupan materinya diperluas, kendati dengan alokasi waktu yang sangat terbatas. Keterbatasan alokasi waktu diatasi dengan pemberlakuan program tutorial PAI pada semester 
sebèlumnya dan menjadi prasyarat bagi mahasiswa yang mengambil mata kuliah PAl, di samping prasyarat lain seperti keterampilan membaca Al-Qur'an: Selanjutnya, Elan Sumarna (2009) menyebut materi-materi silabus mata kuliah PAI dengan cakupan: (1) Metode Memahami islam; (2) Manusia, Agama dan Islam; (3) Al-Qur'an: Memahami dan Menghampirinya; (3)Al-Hadits: Sumber Kedua Ajaran Islam; (4) ljtihad: Sumber dan Metodologi Hukum islam; Tauhidullah: Menghayati Kehadiran Allah; (5) Dzikir, Sholat dan Doa; (6) Cinta, Akhlaq dan Ámal Sholeh; (7) Amar Ma'ruf Nahyi al-Munkar; (8) Jihad; (9) Keindahan Hidup Setelah Mati; (10) Tasawuf dan Tharikat; dan (1.1) Konsep Keluarga dalam Istam.

Demikian gambaran sekilas kedudukan mata kuliah PAl yang pada satu sisi sejajar dengan mata kuliah dasar umum (MKDU) lainnya, namun di sisi lain mempunyai keluasan materi dan misi yang demikian luas karena hampir mencakup semua sisi kehidupan. Karena cakupan materi yang demikian luas tersebut, disinyalir merupakan penyebab timbuinya kelemahan atau kekurangjelasan tujuan ranah afektif yang dirumuskan sebagian besar dosen atau pendidik PAl. Disamping itu, disadari bahwa tujuan afektif lebih sulit diukur bila dibandingkan dengan ranah kognitif maupun psikomotorik (Daradjat, 2010).

\section{Teori dan Perkembangan Ranah Afektif}

PAI merupakan salah satu mata kuliah yang sarat dengan ranah afektif. Karakteristik afektif setidaknya memiliki tiga kriteria, yakni: (1) melibatkan perasaan dan emosi seseorang; (2) bersifat khas; dan (3) memiliki intensitas, arah dan target atau sasaran. Intensitas merupakan tingkat atau kekuatan perasaan. Misalnya beberapa perasaan dianggap lebih kuat dari perasaan lain, seperti "cinta" bagi sebagian orang dianggap tingkat yang lebih kuat dari sekedar "sayang". Arah perasaan bisa positif (perasaan baik) atau sebaliknya (negatif). Misalnya, 'senang' dianggap perasaan yang positif, sedangkan 'benci' merupakan perasaan negatif. Sedangkan . target atau sasaran mengacu pada objek, aktivitas, atau ide sebagai arah dari perasaan.

Arah dan intensitas perasaan dapat digambarkan sebagai sesuatu yang kontinum (Anderson, 1981). Titik:tengah kontinum tersebut merupakan titik netral, dan dari titik tengah ke arah tertentu merupakan arah positif serta sebaliknya merupakan arah negative sebagaimana tergambar sebagai berịut:

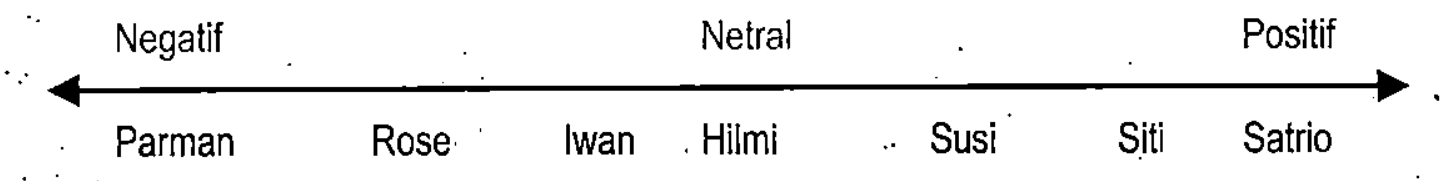

Gambar 1.

Ilustrasi kontinum sikap peserta didik terhadap mata*kuliah tertentu.

Bila 'sikap' dikaitkan deñgan kebutuhan individu misalnya, maka setiap individu memiliki kebutuhan yang berbeda tingkatannya. Glare W. Grave (diadaptasi dari Harsey dan Blanchard, 1993) mengembangkan hirarki kebutuhan individu pada lima tingkat sebagai berikut: (1) kebutuhan fisiologis, 92) kebutuhan keselamatan, (3) kebutuhan social , (4) kebutuhan harga diri, dan (5) kebutuhan aktualisasi diri. Terdapat individu yang mengutamakan tingkat kebutuhan tertentu kendati bagi individu lain kebutuhan tersebut berada pada tingkatyang lebih rendah. Ilustrasi ini menunjukkan struktur kebutuhan sosial lebih besar dari kebutuhan lainnya. 
UNISIA, VOL. XXXIII No. 74 JANUARI 2011

\begin{tabular}{|c|c|c|}
\hline & Aktualisasi Diri & \\
\hline & Harga Diri & \\
\hline & Sosial & \\
\hline & Keselamatan & \\
\hline Fisiologis & \\
\hline
\end{tabular}

Gambar 2.

Struktur kebutuhan sosial merupakan kebutuhan yang paling besar, kendati bukan merupakan kebutuhan tingkat paling tingi

Pada perkembangan dan kondiși yang lain, struktur kebutuhan harga diri dan aktualisasi diri biasanya menjadi kebutuhan yang paling besar. Hal ini terjadi bila tiga kebutuhan di bawahnya sudah relatif terpenuhi. Dengan demikian strukturnya dapat digambarkan sebagaimana berikut:

\begin{tabular}{|l|l|}
\hline \multicolumn{2}{|c|}{ Aktualisasi Diri } \\
\hline \multicolumn{2}{|c|}{ Harga Diri } \\
\hline \multicolumn{2}{|c|}{ Sosial } \\
\hline \multicolumn{2}{|c|}{ Keselamatan } \\
\hline Fisiologis \\
\hline
\end{tabular}

Gambar 3

Struktur kebutuhan aktualisasi diri dan harga diri merupakan dua puncak kebutuhan yang paling besar

. Téori perkembangan afektif salah satunya diformulasikan oleh Dupont pada tahun 1976-an di mana dasar teori yang dikembangkannya sesuai dengan model perkembangan kognitif dari Piaget (Lecapitaine, 1980). Konsep utama teori tersebut menyatakan bahwa: pertama, afeksi merupakan getaran refleksi disértai perubahan psikologis dan tendensi bertindak; kedua, perkembangan afektif memiliki komponen struktur dan dan organisasional di mana hal ini menimbulkan respon afektif yang tidak dapat diulang; dan ketiga, perkembangan afektif terdiri dari enam tahap sebagai berikut:

\begin{tabular}{|c|l|l|}
\hline No. & \multicolumn{1}{|c|}{ Tahap } & \multicolumn{1}{|c|}{ Karakteristik } \\
\hline 1 & Impersonal & Pribadiyang tidak jelas (afekyang masih menyebar) \\
\hline 2 & Heteronomi & Pribadi yang jelas (afekunilateral) \\
\hline 3 & Antarpribadi & Pribadi-teman sejawat (afek mutual) \\
\hline 4 & Psikologis-personal & Afekyang dapat dibedakan satu sama lain (afek interaktifyang kompleks) \\
\hline 5 & Otonomi & $\begin{array}{l}\text { Pusat afek di sekitar konsep abstrak tentang otonomi diri dan orang lain } \\
\text { (afekyang didominasi oleh sifat otonomi) }\end{array}$ \\
\hline 6 & Integritas & Pusat afek di sekitar konsep abstrak integritas diri dan orang lain \\
\hline
\end{tabular}

Sumber: Lecapitaine (1980:9) 
Penting untuk dipahami bahwa pengembangan karakteristik afektif pada peserta didik memerlukan upaya secara sadar dan sistematis. Terjadi tidaknya proses kegiatan pembelajaran dalam ranah afektif dapat - diketahui dari tingkah laku peserta didik yang menunjukkan adanya kesenangan belajar semisal perasaan, emosi, minat, sikap dan apresiasi yang positif menimbulkan tingkah laku yang konstruktif dalam diri peserta didik. Perasaan dapat mengontrol tingkah'laku, sedangkan pikiran (kognisi) seringkali tidak (Anderson, 1981).

\section{Tingkatan Ranah Afektif}

Menurut taksonomi Krathwohl (1964), tingkatan ranah afektif setidaknya mencakup lima tingkat hirarkis, yaitu: receiving (pengenalan); responding (pemberian respon), valuing (penghargaan), organization . (pengorganissian), dan characterization (pengamalan). Kelimanya tingkat tersebut dapat digambarkan sebagai berikut:

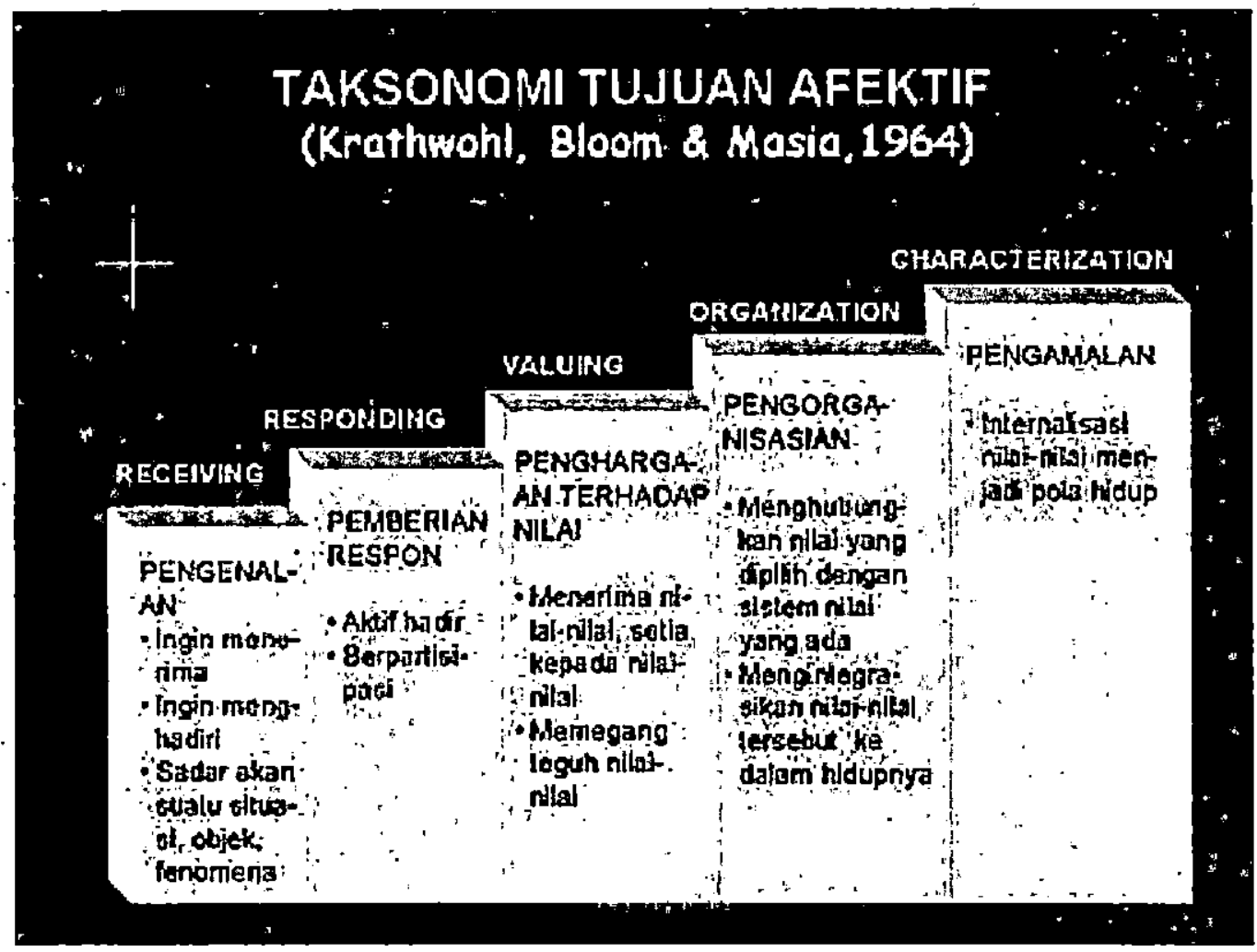

Gambar 4

Tingkatan ranah afektif

Sumber: Krathwohl (1964)

Pada tingkat receiving atau attending, peserta didik memiliki keinginan memperhatikan suatu fenomena khusus atau stimulus. Tugas pendidik mengarahkan perhatian peserta didik pada fenomena yang menjadi objek pembelajaran afektif. Misalnya pendidik mengarahkan peserta didik agar senang membaca, senang bekerjasama, dan sebagainya sesuai dengan pokok bahasan dalam. PAl. Kesenangan ini akan menjadi kebiasaan, dan hal ini yang diharapkan, yaitu kebiasaan yang positif.

Responding merupakan partisipasi aktif peserta didik, yaitu sebagai bagian dari perilakunya. Pada tingkat ini peserta didik tidak saja memperhatikan fenomena khusus tetapi ia juga bereaksi. Hasil pembelajaran pada.ranah ini menekankan pada pemerolehan respons, berkeinginan memberi respons, atau kepuasan dalam memberi respons. Tingkat yang tinggi pada kategori ini adalah minat, yaitu hal-hal yang menekankan pada 
pencarian hasil dan kesenangan pada aktivitas khusus: Misalnya senang membaca Al-Qur'an dan mendalami petunjuk di dalamnya, senang membantu, senang terhadap kebenaran dan sebagainya.

Tingkat valuing melibatkan penentuan nilai, keyakinan atau sikap yang menunjukkan derajat internalisasi dan komitmen. Derajat ini terentang mulai dari menerima suatu nilai, misalnya keinginan untuk meningkatkan keterampilan, sampai pada tingkat komitmen. Valuing atau penilaian berbasis pada internalisasi dari seperangkat nilai yang spesifik. Hasil belajar pada tingkat ini berhubungan dengan perilaku yang konsisten dan stabil agar nilai dikenal secara jelas. Dalam tujuan pembelajaran PAI, penilaian ini diklasifikasikan sebagai sikap keberagamaan.

Pada tingkat organization, nilai satu dengan nilai lain dikaitkan, konflik antarnilai diselesaikan, dan mulai membangun sistem nilai internal yang konsisten. Hasil pembelajaran pada tingkat ini berupa konseptualisasi nilai atau organisasi sistem nilai. Misalnya pengembangan filsafat hidup yang Islami secara subtansial (tidak fanatisme buta terhadap madzhab atau golongan tertentu).

Tingkat ranah afektif tertinggi adalah characterization nilai. Pada tingkat ini peserta didik memiliki sistem nilai yang mengendalikan perilaku sampai pada waktu tertentu hingga terbentuk gaya hidup. Hasil pembelajaran pada tingkat ini berkaitan dengan pribadi, emosi, dan sosial atau membentuk karakter pribadi muslim yang utuh sebagaimana pribadi Rasulullah Muhammad SAW.

\section{Penilaian dan Evaluasi Ranah Afektif}

Secara nasional ditetapkan cara penilaian kelompok pelajaran agama dan akhlak mulia dilàkukan dengan: (a) Pengamatan terhadap perubahan perilaku dan sikap untuk menilai perkembangan afeksi dan kepribadian peserta didik; dan (b) Ujian, dan/atau penugasan untuk mengukur aspek kognitif peserta didik. Sementara teknik penilaiannya dilakukan dengan: (a) tes tertulis, (b) tes praktik, (c) pengamatan, (d) penugasan individual ațau kelompok, (e) tes lisan, (f) portofolio, (g) jurnal inventori, $(\mathrm{h})$ penilaian diri, dan (i) penilaian antarteman. Hasil penilaian berupa skor (kuantitatif) untuk aspek kognitif, dan bentuk deskripsi naratif (kualitatif) untuk àspek afektif dan kepribadian (BNSP, 2006).

Menurut Anderson (1981) setidaknya terdapat dua metode yang dapat digunakan untuk mengukur ranah afektif, yaitu metode observasi dan metode laporan diri. Penggunaan metode observasi berdasarkan pada asumsi bahwa karakteristik afektif dapat dilihat dari perilaku atau perbuatan yang ditampilkan dan/atau reaksi psikologis. Metode laporan diri berasumsi bahwa yang mengetahui keadaan afeksi seseorang adalah dirinya sendiri. Namun hal ini menuntut kejujuran dalam mengungkap karakteristik afektif diri șendiri.

Dalam pengembangan spesifikasi instrumen afeksi dilakukan dengan terlebih dahulu menentukan definisi konseptual yang berasal dari teori-teori yang sesuai. Selanjutnya mengembangkan definisi operasional berdasarkan kompetensi dasar, yaitu kompetensi yang dapat diukur. Definisi operasional ini kemudian dijabarkan mịnjadi sejumlah indikator. Indikator merupakan pedoman dalam menulis instrumen. Tiap indikator bisa dikembangkan dua atau lebih butir pertanyaan atau pernyataan.

Penilaian dan evaluasi pada ranah afektif, setidaknya terkait dengan lima (5) tipe afektif yaitu sikap, minat, konsep diri, nilai, dan moral. Kelima tipe ini yang biasanya dilakukan penilaian dan/atau pengukuran dikaitkan dengan materi tertentu termasuk materi PAI. Berikut penjelasan singkat kelima tipe afektif tersebut dan instrumentyang digunakan.

\section{a. Sikap}

Sikap merupakan suatu kencenderungan untuk bertindak secara suka atau tidak suka terhadap suatu objek. Sikap dapat dibentuk melalui cara mengamati dan menirukan sesuatu yang positif, kemudian melalui 
penguatan serta menerima informasi verbal maupun nonverbal. Perubahan sikap dapat diamati mulai dalam proses pembelajaran, tujuan yang ingin dicapai, keteguhan, dan konșistensi terhadap sesuatu. Penilaian sikap adalah penilaian yang dilakukan untuk mengetahui sikap peserta didik terhadap objek di atas, bahkan termasuk pada mata kuliah PAI dan sub-sub pokok bahasan yang ada di.dalamnya.

Sikap peserta didik terhadap PÄl, terhadap sub-sub pokok bahasan di dalamnya bahkan sikap terhadap Islam sebagai agama dan keyakinannya, penting untuk ditingkatkan. Sikap peserta didik ini harus lebih positif - setelah peserta didik mengikuti pembelajaran PAI dibanding sebelum mengikuti pembelajaran. Perubahan ini merupakan salah satu indikator keberhasilan pendidik dalam melaksanakan proses pembelajaran. Untuk itu pendidik harus membuat rencana pembelajaran termasuk pengalaman belajar peserta didik yang membuat sikap peserta didikterhadap mata pelajaran menjadi lebih positif.

Pertanyaan tentang sikap, meminta responden menunjukkan perasaan yang positif atau negatif terhadap suatu objek tertentu, seperti mata kuliah PAl, pokok bahasan tertentu, sikap ke-Islam-an tertentu, dan lain-lain. Kata-kata yang sering digunakan pada pertanyaan sikap antara lain dengan menyatakan arah perasaan seseorang, misalnya menerima-menolak, menyenangi-tidak menyenangi, baik-buruk, diingini-tidak diingini dan lain sebagainya. Di antara contoh indikator sikap terhadap mata kuliah PAI antara lain: membaca buku PAl, mempelajari PAl, melakukan interaksi dengan dosen PAl, mengerjakan tugas PAl, melakukan diskusi tentang PAl, memiliki buku PAI, dan lain-lain. Sementara contoh pernyataan untuk kuesioner yang digunakan sebagai instrument dalam penilaian antara lain: saya senang membaca buku-buku PAl, tidak semua orang harus belajar . PAI, saya jarang bertanya pada dosen tentang pelajaran PAl, saya tidak senang pada tugas mata kuliah PAI, memiliki buku PAl penting untuk semua peserta didik, dan lain-lain.

\section{b. Minat}

Secara umum 'minat atau keinginan' dipahami sebagai kecenderungan hati yang tinggi terhadap sesuatu. Sementara dalam disiplin psikologi, 'minat' adalah suatu disposisi yang terorganisir melalui pengalaman yang mendorong seseorang untuk memperoleh objek khusus, aktivitas, pemahaman, dan keterampilan untuk tujjuan perhatian atau pencapaian (KBBI, 1990). Hal penting pada minat adalah intensitasnya. Secara umum minat termasuk karakteristik afektif yang memiliki ințensitas tinggi.

Penilaian minat pada konteks PAl antara lain dapat digunakan untuk:

1) Mengetahui minat peserta didik sehingga mudah untuk pengarahan dalam pembelajaran,

2). Menggambarkan keadaan langsung atau keterkaitan antara pokok.bahasan tertentu dalam PAI dengan kondisi riil di masyarakat,

3) Mengelompokkan peserta didikyang memiliki minat sama,

4) Acuan dalam menilai kemampuan peserta didik secara keseluruhan dan memilih model atau metode pembelajaran yang tepat,

5) Meningkatkan motivasi belajar peserta didik dan menerapkan nilai-nilai agama/nilai Islami dalam kehidupan nyata di dalam kehidupan.

Indikator minat terhadap mata kuliah PAI dapat ditilik dari: memiliki catatan mata kuliah PAl, berusaha memahami PAI, memiliki buku-buku PAI, mengikuti pembelajaran PAl, dan lain-lain. Sementara contoh pernyataan pada kuesioner untuk penilaian PAI dapat ditilik dari: kelengkapan catatan mata kuliah PAI peserta didik, catatan mata kuliah PAl terdapat coretan-coretan tentang hal-hal yang penting, menyiapkan pertanyaan sebelum mengikuti pembelajaran PAl, berusaha memahami mata kuliah PAl, senang mengerjakan soal PAl, berusaha selalu hadir pada pembelajaran dan praktikum PAl, dan lain-lain. 


\section{c. Konsep Diri}

Menurut Smith, konsep diri adalah evaluasi yang dilakukan individu terhadap kemampuan dan kelemahan yang dimiliki. Target, arah, dan intensitas konsep diri pada dasarnya seperti ranah afektif yang lain. Arah konsep diri bisa positif atau negatif, dan intensitasnya bisa dinyatakan dalam suatu daerah kontinum, yaitu mulai dari rendah sampai tinggi.

Konsep diri ini penting untuk mengembangkan karakter dan kepribadian peserta didik, yaitu dengan mengetahui kekuatan dan kelemahan diri sendiri. Hal ini diharapkan dapat menumbuhkan sikap introspeksi (muhasabatu al-nafs) pada peserta didik, optimisme (tafa' 'ul) dengan kelebihan yang dimilikinya namun juga tetap sadar dengan kekurangan atau kelemahannya. berikut:

Penilaian konsep diri dapat dilakukan dengan penilaian diri. Kelebihan dari penilaian diri adalah sebagai

1) . Pendidik mampu mengenal kelebihian dankekurangan peserta didik.

2) Peserta didik mampu merefleksikan kompetensi yang sudah dicapai.

3) Pernyataan yang dibuat sesuái dengan keinginan penanya.

4) Memberikan motivasi diri dalam hal penilaian kegiatan peserta didik.

5) Peserta didik lebih aktif dan berpartisipasi dalam proses pembelajaran.

6) . Dapat digunakan untuk acuan menyusun bahan ajar dan mengetahui standar input peserta didik.

7) Peserta didik dapat mengukur kemampuan untuk mengikuti pembelajaran.

8) Peserta didik dapat mengetahui ketuntasan belajarnya.

9) - Melatih kejujuran dan kemandirian peserta didik.

10) . Peserta didikmengetahui bagian yang harus diperbaiki.

11). Peserta didikmemahami kemampuan dirinya.

12). Pendidikmemperoleh masukan objektif tentảng daya serap peserta didik.

13) Mempermudah pendidik untuk melaksanakan remedial, hasilnya dapat untuk instropeksi pembelajaran yang dilakukan.

14) Peserta didik belajar terbuka dengan orang lain.

15) Peserta didikmampu menilai dirinya.

16) Peserta didik dapat mencari materi sendiri.

17). Peserta didik dapat berkomunikasi dengan temannya.

Contoh-contoh indikator konsep diri antara lain: memilih șub pokok bahasan yang mudah dipahami, memiliki kecepatan memahami bidang dan pokok bahasan tertentu, mengukur kekuatan dan kelemahan dalam mengkomunikasikan konsep keagamaan tertentu, dan lain-lain. Sementara itu pernyataan untuk instrument antara lain dapat dinyatakan seperti: Saya sulit mengikuti pelajaran PAl, saya mudah memahami pembahasan ijtihad, saya mudah menghapal ayat-ayat Al-Qur'an tentang hukum, saya mampu membaca dan menerjemahkan hiadits hukum dengan baik, saya merasa sulit memahami konsep mahabbah dalam tashawuf, dan lain-lain. 


\section{d. Nilai}

Nilai merupakān suatu keyakinan tentang perbuatan; tindakan, atau perilaku yang dianggap baik dan yang dianggap buruk. Bila sikap mengacu pada suatu organisasi sejumlah keyakinan sekitar objek spesifik atau situasi; maka nilai mengacu pada keyakinan. Target nilai cenderung menjadi ide, atau kadang juga berupa sikap dan perilakui: Arah nilai dapat positif dan dapat negatif. Intensitas nilai dapat dikatakan tinggi atau rendah tergantung pada situasi dan nilai yang diacu. Proses pendidikan dan pembelajaran PAI harus membantu peserta didik menemukan dan menguatkan nilai yang bermakna dan signifikan bagi dirnya untuk memperoleh kebahagiaan personal dan memberi konstribusi positif terhadap masyarakat.

Inștrumen aspek nilai sebagai bagian dari ranah afektif bertujuan untuk mengungkap nilai dan keyakinan individu. Informasi yang diperoleh berupa nilai dan keyakinan yang positif dan yang negatif. Hal-hal yang positif ditingkatkan sedang yang negatif dikurangi dan akhirnya dihilangkan.

Sebagian dari indikator nilai antara lain adalah: memiliki keyakinan akan peran agama dalam kehidupan, menyakini keberhasilan bila melakukan usaha yang optimal, menunjukkan keyakinan atas kemampuan dirinya, mempertahankan keyakinan akan harapan demi kebaikan bersama. Sementara itu contoh pernyataan untuk kuesioner tentang nilai peserta didik antara lain: saya berkeyakinan bahwa prestasi belajar peserta didik dapat ditingkatkan, saya berkeyakinan bahwa kinerja pendidik sudah maksimal, saya berkeyakinan sistem pendidikan saat ini belum mampu mengubah tingkat kesejahteraan masyarakat secara merata, saya berkeyakinan bahwa perubahan selalu membawa masalah, saya berkeyakinan bahwa hasil yang dicapai peserta didik adalah atas usahanyà, dan lain-lain.

\section{e. Moral}

Piaget dan Kohlbérg · banyak 'disebut teorinya tentang perkembangan moral, bahkạn tidak jarang teorinya menjadi landasan dasar dalam proses pendidikan moral (Kohlberg, 1995). Sekalipun demikian, teơri tersebut bukannya tanpa kritik, di àntaranya karena Kohlberg dianggap mengabaikan hubungan antara judgement moral dan tindakan moral. la dianggap. lebih cenderung pada prinsip moral seseorang melalui penafsiran respon verbal terhadap dilema hipotetikalnya, bukan pada bagaimana sesungguhnya seseorang bertindak atau tindakan moralnya. Disamping itu, teori Kohlberg dinilai mengandung bias budaya dan bias seks / jenis kelamin (Hersh, Miller \& Fielding, 1980).

Seringkali moral berkaitan dengan perasaan salah atau benar terhadap orang lain atau perasaan terhadap tindakan yang dilakukan diri sendiri. Misalnya menipu orang lain, membohongi orang lain, atau melukai orang lain baik fisik maupun psikis. Moral juga sering dikaitkan dengan keyakinan agama seseorang, seperti keyakinan akan perbuatan yang berdosa dan berpahala. Jadi moral berkaitan dengan prinsip, nilai, dan keyakinan seseorang.

Dalam konteks PAI dan moralitas Islam, yang diharapkan adalah sampai pada inti moralitas ke-Islam-an yang diyakini secara substansial adalah moralitas universal atau rahmatan li-'alamien. Sejumlah moralitas substansial yang universai dari moralitas Islam seperti: kejujuran, integritas, keadilan, kebebasan, penghargaan dan lain-lain. Dengan kata lain, dalam keberagamaan ke-lslam-an seseorang, tercipta peserta didik yang tahu dan hapal ajaran agama serta menghayati dan menjadi dasarkepribadiannya.

Sejumlah indikator moral sesuai déngan definisi teoritis antara lain: memegang janji, memiliki kepedulian terhadap orang lain, menunjukkan komitmen terhadap tugas-tugas, memiliki kejujuran dan integritas, dan lainlain. Sementara contoh pernyataan untuk instrumen moral antara lain: bila saya berjanji pada teman, tidak harus menepati; bila berjanji kepada orang yang lebih tua, saya berusaha menepatinya; bila berjanji pada anak kecil, 
saya tidak harus menepatinya; bila menghadapi kesulitan, saya selalu meminta bantuan orang lain; bila ada orang lain yang menghadapi kesulitan, saya berusaha membantu; kesulitan orang lain merupakan tanggung.jawabnya . sendiri; bila bertemu teman, saya selalu menyapanya walau ia tidak melihat saya; bila bertemu dosen, saya selalu memberikan salam, walau ia tidak melihat saya; saya selalu bercerita halyang menyenangkan teman, walau tidak seluruhnyä benar; bila ada orang yang bercerita, saya tidak selalu mempercayainya; dan lain-lain.

Wujud instrument y'ang sering digunakan dạlam penilaian tipe afektif di atas antara lain kuesioner dalam bentuk skala, khususnya untuk sikap minat maupun nilai. Sementara skala yang sering digunakan adalah Skala' . Thurstone, Skala Likert, dan Skala Beda Semantik. Namun demikian dalam tulisan singkat ini, ketiganya tidak dibahas dengan asumsi skala tersebut sudah mafhum (sering digunakan) kendati bukan dalam rangka penilaian atau evaluasi afektifPAI.

\section{Evaluasi PAI di PTU}

Sesuai pengalaman selama menjadi dosen PAI di salah satu PTU; penulis menemukan sejumlah faktor utama yang menjadi persoalan dalam evaluasi PAI. Pertama, acapkali adanya perbedaan persepsi tentang batasan materi-materi yang tidak dapat dievaluasi seperti masalah keimanan, kendati sesungguhnya Al-Qur'an telah mengisyaratkan karakter orang-orang yang beriman. Hal ini terjadi tidak hanya pada pelaksanaan evaluasi PAI namun bermula sejak proses pendidikan PAl dilakukan, terlebih bila pendidikan dan pembelajaran dilakukan melalui pola team teaching.

$\because \quad$ Kedua, persoalan juga muncul karena kadang perumusan tujuan PAl terlalu ideal dan terkesan kurang jelas sehingga sulit diukur keberhasilannya. Hal ini dapat dipahami karena secara psikologis umumnya orang masih menganggap bahwa agama adalah ajaran 'deal' dan universal - dan memang bagaimanapun agama ädalah ajaran ideal dan universal, minimal bagi pemeluknya. Namun di sisi lain, pandangan idealitas dan universalitas ini menjadikan tujuan mata kuliah PAI menjadi terlalu ideal dan terlalu luas.

$\because \quad \quad \quad$ Ketiga, secara umum masih ditemukan persoalan klasik berupa kurangnya kemampuan sebagian besar dosen PAI dalam mengembangkan instrumen PAI pada ranah afektif dan psikomotorik, dan lebih sering terbatas pada ranah kognitif. Kendati demikian, memang diakui banyak ahli bahwa evaluasi untuk ranah afektif cenderung "lebih sulit' bila dibanding ranah lain, namun bukan berarti tidak dapat dilakukan secara ideal. Keempat, persoalan klașik lain sering muncul berupa tingginya rasio dosen dengan mahasiswa sehingga seorang dosen harus mengajar dị luar.kapasitasnya. Hal ini berdampak pada efektivitas pelaksanaan evaluasi.

Terhadap sejumlah persoalan di atas, terdapat sejumlah strategi yang dapat dilakukan dalam usaha meningkatkan proses menilai hasil pendidikan dan pembelajaran PAI secara efektif. Hal ini agar penilaian dapat dilakukan terhadap semua aspek hasil belajar secara serasi dan seimbang sehingga aspek afektif tidak menjadi terabaikan. Sejumlah strategi yang. dimaksud antara lain: (1) perumusan tujuan yang jelas dan tegas sehingga ṃudah dievaluảsi; (2) pencatatan tingkah laku peserta didik; (3) kesinambungan dalam penilaian; (4) kualitas. instrumen dalam penilaian; dan (5) kesesuaian antara aspek yang diukur dengan materi yang disampaikan.

$\therefore \quad$ Selain itu disadari bersama bahwa peserta didik PAI.di PTU adalah orang dewasa, setidaknya secara biologis. Artinya, terdapat sejumlah hal yang berbeda bila dibanding dengan peserta didik anak-anak dan remaja. Oleh karenanya, evaluasi dan penilaian PAl pada PT dapat dilakukan dengan berbagai cara berikut. Pertama, nenugaskan mahasiswa untuk melaporkan aktivitas keagamaan masing:masing, baik yang dilakukan di kampus maupun di lingkungan di mana mahasiswa tinggal. Kedua, model sosio-matriks, yaitu memberikan penilaian dan merengking 5 orang teman-sekelasnya yang paling tinggi sikap kegamaannya, yang di dalamnya antara lain meliputi: (a) cara berpakaian, (b) pelaksanaan sholat, (c) kejujuran, (d) aktivitas keagamaan, (e) menempati janji, 
(f) pengetahuan dan wawasan keislaman, (g) sopan santun, (h) membaca al-Qur'an, (i) pergaulan dengan teman dalam kehidupan sehari-hari baik dilihat dari bahasa maupun perilakunya, (j) dan lain-lainyang dianggap perlu.

Ketiga, observasi baik langsung maupun tidak langsung untuk mencari informasi dari berbagai sumber tentang perilaku keagamaan mahasiswa peserta didik PAl.'Informan yang bisa dijadikan sumber antara lain dapat diperoleh dari dosen-dosen jurusan, himpunan mahasiswa dan tempat tinggal mahasiswa selama masih bisa dilacak. Keempat, mengadakan studi sosial keagamaan di sekitar tempat tinggalnya. Mahasiswa ditugaskan untuk mendata kehidupan keagamaan dan kemakmuran masjid yang dekat dengan tempat tinggalnya.

Sementara itu, mekanisme penilaian hasil belajar PAI pada PTU antara lain dapat dilakukan dengan berbagai cara. Sejumlah cara dimaksud antara lain sebagai berikut. Pertama, perancangan penilaian PAl oleh dosen PAI dilakukan saat pengembangan program pembelajaran, baik dalam bentuk silabus maupun rencana pelaksanaan pembelajaran (RPP). Kedua, UTS dan UAS PAl adalah teknik penilaian untukmengukurketuntasan penguasaan kompetensi PAl mahasiswa pada tengah semester dan akhir semester. Ujian ini dilakukan oleh dosen PAI di bawah koordinasi satuan pendidikan.

$\because \quad \quad$ Ketiga, penilaian tugas terstruktur dan mandiri adalah teknik penilaian untuk mengukur kedalaman pengamalan ajaran agama dan aktivitas keagamaan mahașiswa dalam keseharian. Keempat, penilaian tugas kelompok melalui diskusi adalah teknik untuk mengukur keluasan pemahaman dan pengetahuan mahasiswa akan ajaran agama Islam. Kelima, penilaian kehadiran adalah teknik untuk menilai komitmen mahasiswa dalam melaksanakan kewajibannya sebagai seoràng peserta didik; dan keenam, penilaian sosiometrik, yakni teknik untuk mengetahui sikap dan amaliah mahasiswa dalam pandangan lingkungannya.

. Demikian sekilas sejumlah persoalan dan cara atau mekanisme yang bisa ditempuh sebagai tawaran untukmengoptimalkan fungsi evaluasi PAI pada PTU. Namun demikian pada kondisi tertentu seorang mahasiswa dinyatakan lulus apabila telah memillkik nilai PAI minimal nilai B dengan sejumlah kompetensi dasar. Kompetensikompetenși dasar dimaksud misalnya adalah: mampu menjawab soal UAS dan UTS, mampu membaca al-Qưr'an dengan tartil, mampu mempraktikkan gerakan sholat, melaporkan aktivitas keagamaan di mana ia tinggal, mampu menghapal minimal 10 doa harian, kehadiran dan aktivitas di kelas, serta mampu menghafal surat alNáas sampai al-Bayyinah misalnya. Kendati ini masih dianggap minimalis, namun mudah-mudahan tidak ada kata bosan untuk beranjak ke arah yang lebih baik.
$r:$

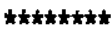
DAFTAR PUSTAKA
Anderson, Lorin W. (1981) Assessing Affective Characteristic in the Schools. Boston: Allyn an d Bacon, Inc.
Anonim (2006), Panduan Penilaian Kelompok Pelajaran Agama dan Akhlak Mulia Jakarta: Badan Standar
$\therefore \quad$ Nasional Pendidikan(BNSP).
Bloom, B. S. ed. etal. (1956) Taxonomy of Educational Objectives: Handbook 1. New York: David McKay.
Daradjat, Zakiah (2010) pada Draf Standar Penilaian Pendidikan Agama Islam Pada Perguruan Tinggi Umum.
$\therefore$. Jakarta: Direktorat Jendral Pendidikan Perguruan Tinggi Islam Kemeterian Agama Rl.
Zैuuhdi, Darmiyati (2008) Humanisasi Pendidikan.Jakarta: Bumi Aksara
Departemen Pendidikan Nasional (1990) Kamuis Besar Bahasa Indonesia. Jakarta: Balai Pustaka 
ÜNISIA, VOL. XXXIII No. 74 JANUARI 2011.

2007. Peraturan Menteri Pendidikan Nasional (Permendiknas) nomor 20 tahun 2007 tentang Standar. Penilaian

Gronlund, N. E. (1978) Stating Objectives for Classroom Instruction 2nded. New York: MacMillan Publishing.

Hersey, Paul and Kenneth H. Blanchard. (1993) Management of Organization Behavior. New Jersey: PrenticeHall, Inc.

Hersh, Miller \& Fielding (1980) Model of Moral Education:AnAppraisal. New York: Longman Inc.

Kohlberg, Lawrence (1985) Tahap-tahap Perkembangan Moral, terj. John de Santo dan Agus Cremers. Yogyakarta: Kanisius.

Krathwohl; D. R. ed. et al. (1964) Taxonomy of Educational Objectives: Handbook II, Affective Domain. New York: David McKay.

Lecapitaine, John E. (1980) The Differential Effects of Three Psychological Education Curricula Affective and. Moral Development. Dissertation. Boston: Boston University School.

Syahidin (2010), pada Draf Standar Penilaian Pendidikan Agama Islam Pada Perguruan Tinggi Umum. Jakarta: - Direktorat Jendral Pendidikan Perguruan Tinggi Islam Kemeterian Agama RI

Sumarna, Elan (2009) Silabus dan Satuan Acara Perkuliahan (SAP) mata kuliah PÁl Semester Genap.

Bandung: Fakultas Pendidikan llmu Pengetahuan Sosial UPI 